\title{
Pengaruh Latihan Acceleration Sprints dan In-out Sprint Terhadap Kecepatan
}

\section{Effects of Acceleration Sprints and In-out Sprints Exercise Against Speed}

\author{
Wawan Setiawan $^{1}$, I Made Rajat Sanjaya ${ }^{2}$, Puji Setyaningsih $^{3}$ \\ 1,3Fakultas Olahraga dan Kesehatan, Universitas PGRI Banyuwangi, Indonesia \\ ${ }^{2}$ SMP N 3 Kuta Selatan, Indonesia \\ email: wawan11setiawan11@gmail.com¹, rajatdiah@gmail.com², myedu37@gmail.com³ \\ do): https://doi.org/10.20884/1.paju.2021.3.1.4701
}

\begin{abstract}
Abstrak
Latihan kondisi fisik khususnya kecepatan sangat dibutuhkan oleh seorang atlet, karena kecepatan merupakan komponen kondisi fisik yang sangat penting untuk menunjang keberhasilan di dalam sebagian besar cabang olahraga. Latihan yang dimaksudkan untuk meningkatkan kecepatan dan kelincahan adalah latihan acceleration sprints dan in-out sprint. Tujuan dari penelitian ini yaitu untuk menganalisis tentang: (1) pengaruh latihan acceleration sprints terhadap kecepatan, (2) pengaruh latihan in-out sprint terhadap kecepatan, dan (3) perbedaan besar pengaruh latihan acceleration sprints dan in-out sprint terhadap kecepatan. Sasaran penelitian ini adalah mahasiswa putra semester IV angkatan 2014, Jurusan Pendidikan Jasmani Kesehatan dan Rekreasi, Fakultas Olahraga dan Kesehatan, Universitas Pendidikan Ganesha Singaraja dengan jumlah sampel sebanyak 36 orang. Jenis penelitian yang digunakan adalah kuantitatif dengan metode eksperimen semu.Proses pengambilan data dilakukan dengan tes kecepatan(lari sprint 30 meter) pada saat pretest dan posttest. Selanjutnya data hasil penelitian dianalisis dengan menggunakan bantuan SPSS seri 21.0. Hasil penelitian sebagai berikut : (1) latihan acceleration sprints berpengaruh signifikan terhadap peningkatan kecepatan. (2) latihan in-out sprint berpengaruh signifikan terhadap peningkatan kecepatan. (3) Tidak terdapat perbedaan pengaruh yang signifikan antara latihan acceleration sprints dan latihan in-out sprint terhadap kecepatan. Berdasarkan analisis data tersebut, dapat disimpulkan bahwa latihan acceleration sprints dan in-out sprint berpengaruh signifikan terhadap kecepatan.
\end{abstract}

Kata Kunci: Acceleration Sprints, In-out Sprint, Kecepatan,

\footnotetext{
Abstract

Exercise the physical condition of especially speed were really needed by an athlete, because of its speed is a component a physical condition that is very important to support the success in most of the sports. So that the physical Alamat Koresponden: Fakultas Olahraga dan Kesehatan, Universitas PGRI Banyuwangi Email: wawan11setiawan11@gmail.com (c) (i) 
condition of in kinds of sports need to trained by the exercise of good. Exercises intended to increase the speed is a training exercise acceleration sprints and inout sprint. The aim of this study were to analyze (1) the effects of acceleration sprints exercise towards speed, (2) the effects of in-out sprint exercise towards speed, and (3) a big difference on the effect of acceleration sprints and in-out sprint exercises towards the speed. The samples of this research were 36 male students of The first half IV the 2014, of Education Physical Health and Recreation, the Faculty Sports and Health, University Education Ganesha Singaraja. This research used a quantitative-quasi experimental model. The research design used was non-randomized control group pretest posttest design, and the data were analysed by using ANOVA. The data were gained through pretest and posttest on the speed by using 30 meters run sprints. After that, the data were analyzed by using SPSS 21.0. The results of the study shows that (1) acceleration sprints exercise gives significant effect towards the improvement of speed. (2) in-out sprint exercise gives significant effect towards the improvement of speed, (3) exercise acceleration sprints and in-out sprint not there is a difference influence to the speed. Post hoc calculation show that acceleration sprints exercises provide better results (effective) towards the speed. Based on data analysis towards the improvement of speed.

Keywords: Acceleration Sprints, In-out Sprint, Speed

\section{PENDAHULUAN}

Olahraga merupakan suatu kebutuhan bagi manusia. Dianggap kebutuhan karena manusia adalah makhluk yang bergerak. Manusia dalam melakukan aktivitasnya tidak pernah terlepas dari proses gerak, sebab tidak ada kehidupan tanpa adanya gerakan. Dalam pelaksanaannya, olahraga bersifat universal karena olahraga dapat dilakukan oleh seluruh lapisan masyarakat. Begitu besar peran olahraga terhadap kehidupan manusia, sehingga olahraga dapat dijadikan sebagai sarana atau media untuk berekreasi, mata pencarian, pendidikan, kesehatan, kebudayaan bahkan sebagai sarana untuk mencapai prestasi. Tidak dapat dipungkiri bahwa olahraga telah banyak memberikan sumbangannya untuk kebahagian umat manusia.Ini berarti olahraga sebagai aktivitas fisik yang dapat memberikan kepuasan kepada pelakunya. Disamping itu, olahraga merupakan salah satu karakter suatu bangsa atau masyarakat.

Adapun latihan dalam olahraga adalah suatu proses yang direncanakan dalam berbagai macam tahap serta dilaksanakan secara berkelanjutan. Menurut Lakshmikrishnan \& Sivakumar (2013) latihan adalah proses ilmiah berbasis pedagogis terorganisir, terencana dan sistematis pada kemampuan dan kesiapan kinerja dengan bertujuan kesempurnaan olahraga dan peningkatan kinerja dalam konteks kompetisi olahraga. Menurut Sukadiyanto \& Muluk (2011) bahwa proses latihan yang dilakukan 
Wawan Setiawan, I Made Rajat Sanjaya \& Puji Setyaningsih | Pengaruh Latihan Acceleration Sprints dan Inout Sprint Terhadap Kecepatan

secara cermat, berulang-ulang dengan kian meningkat beban latihannya memungkinkan kesegaran jasmani seseorang kian terampil, kuat dan efisien gerakannya.

Dalam melakukan latihan terdapat kondisi fisik yang mendasari kemampuan seseorang.Sehingga pembinaan kondisi fisik harus mendapat perhatian yang serius dan pembinaannya harus menggunakan metode latihan yang baik dan benar. Adapun komponen-komponen kondisi fisik menurut Sukadiyanto \& Muluk (2011) bahwa komponen dasar dari biomotorolahragawan meliputi kekuatan, ketahanan, kecepatan, koordinasi,dan fleksibilitas. Adapun komponen-komponen yang lain merupakan perpaduan dari beberapa komponen sehingga membentuk satu sebutan dari gabungan komponen tersebut. Diantaranya, seperti power merupakan gabungan dari kekuatan dan kecepatan, kelincahan merupakan gabungan dari kecepatan dan koordinasi.

Melihat unsur-unsur pelatihan fisik tersebut, kecepatan (speed) dan kelincahan (agility)merupakan salah satu unsur latihan fisik yang diperlukan di dalam banyak cabang olahraga (Gamble, 2012). Menurut Ratamess (2012) kecepatan merupakan kemampuan untuk melakukan gerakan-gerakan yang sejenis secara berturut-turut dalam waktu sesingkat-singkatnya, atau kemampuan menempuh jarak dengan cepat. Adapun pengertian kelincahan menurut Sucharitha et al., (2014) adalah kemampuan untuk mempertahankan atau mengontrol posisi tubuh saat cepat berubah arah selama rangkaian gerakan.

Metode latihan kecepatan dan kelincahanmerupakan bentuk latihan yang cukup banyak dan beraneka ragam, akan tetapi dalam penelitian ini peneliti menggunakan dua bentuk latihan dari macam-macam bentuk latihan untuk meningkatkan kecepatan dan kelincahan, yaitu latihan accelerationsprints dan latihan in-out sprint. Menurut Deuster et al., (2013) acceleration sprints adalah latihan pengembangan kecepatan, dengan cara berlari cepat dan bertahap meningkat dari jogging, striding dan sprint dilakukan secara berulang-ulang sedangkanin-out sprint adalah periode sprint berkecepatan tinggi yang diikuti dengan lari cepat untuk melemaskan tubuh pada jarak yang sama (Gatz, 2009). Alasan peneliti memilih kedua bentuk latihan tersebut didasarkan karena latihan tersebut lebih mendominasi pembentukan kecepatan (speed) dan kelincahan (agility).

Dari uraian latar belakang di atas, maka peneliti tertarik untuk melakukan penelitian latihan acceleration sprints dan in-out sprint pada mahasiswa Putra Semester IV angkatan 2014, Jurusan Pendidikan Jasmani Kesehatan dan Rekreasi, Fakultas Olahraga 
dan Kesehatan, Universitas Pendidikan Ganesha, Singaraja Tahun Ajaran 2015/2016, guna meningkatkan kualitas kondisi fisik terutama kecepatan

\section{METODE}

\section{Jenis dan Rancangan Penelitian}

Jenis penelitian yang digunakan dalam penelitian ini adalah penelitian kuantitatif dengan menggunakan metode eksperimen semu (quasi experimental). Rancangan penelitian yang digunakan dalam penelitian ini adalah "non-randomized control group pretest posttest design" tertera pada tabel 1 dibawah ini.

Tabel 1. Metode Penelitian.

\begin{tabular}{llll}
\hline Kelompok & Pretest & Treatment & Posttest \\
\hline E1 & T1 & X1 & T2 \\
\hline E2 & T1 & X2 & T2 \\
\hline K & T1 & - & T2 \\
\hline
\end{tabular}

\section{Populasi dan Sampel Penelitian}

Populasi adalah keseluruhan individu dalam penelitian. Populasi dalam penelitian ini adalah seluruh mahasiswa putra semester IVangkatan 2014, Jurusan Pendidikan Jasmani Kesehatan dan Rekreasi, Fakultas Olahraga dan Kesehatan, Universitas Pendidikan Ganesha Singaraja,yang berjumlah 118 mahasiswa putra.

Dari jumlah populasi yang ada untuk menjadi sampel harus memenuhi ketentuanketentuan untuk memenuhi tujuan penelitian. Ketentuan-ketentuan tersebut adalah:

1. Terdaftar sebagai mahasiswa semester IV angkatan 2014, Jurusan Penjaskesrek, Fakultas Olahraga dan Kesehatan, Undiksha Singaraja.

2. Berjenis kelamin laki-laki.

3. Memiliki usia rata-rata 20 tahun.

Sampel adalah wakil dari populasi yang memiliki karakteristik dari populasi tersebut dan dijadikan pusat perhatian peneliti dalam ruang lingkup serta waktu yang telah ditentukan. Menurut Maksum (2012), merekomendasikan angka 30 sebagai jumlah minimal sampel, karena jumlah 30 secara statistik sudah merupakan sampel besar, dan ketika 30 sampel diambil secara random, maka data akan cenderung berdistribusi normal. Dari hasil ketentuan tersebut maka peneliti merencanakan pengambilan sampel 
Wawan Setiawan, I Made Rajat Sanjaya \& Puji Setyaningsih | Pengaruh Latihan Acceleration Sprints dan Inout Sprint Terhadap Kecepatan

minimal 30 orang dari populasi, menggunakan simple random sampling, dengan cara pengundian. Dari simple random sampling tersebut didapat 36 orang yang digunakan sebagai sampel. Kemudian dilakukan pretest untuk mengetahui kemampuan awal kecepatan. Tes kecepatan menggunakan lari sprint 30 meter.

Hasil pretest tersebut akan dirangking sebelum menempatkan subjek kedalam masing-masing kelompok. Kemudian subjek dibentuk menjadi 3 kelompok, masingmasing kelompok berjumlah 12 orang. Dengan demikian ketiga kelompok tersebut sebelum diberi perlakuan merupakan kelompok yang mempunyai kemampuan yang sama. Apabila pada akhirnya ada perbedaan maka hal itu disebabkan oleh pengaruh perlakuan yang diberikan. Pembagian kelompok dalam penelitian ini dengan cara ordinal pairing.

\section{Instrumen Penelitian}

1. Tes lari Sprint 30 meter

a. Tahap Pelaksanaan

1) Pretest Kecepatan (Speed) dengan: tes lari sprint 30 meter (Sudhesh, 2013).

a) Tujuan : Untuk mengukur kecepatan

b) Alat dan fasilitas yang diperlukan.

(1) Lintasan lurus, rata, tidak licin, mempunyai lintasan lanjutan, berjarak 30 meter.

(2) Stopwatch.

(3) Serbuk kapur.

(4) Formulir tes.

(5) Alat tulis.

c) Petugas tes.

(1) Pemandu tes.

(2) Pencatat waktu.

d) Pelaksanaan standar operasional prosedur (SOP) tes kecepatan (speed)adalah sebagai berikut:

(1) Pesertasiap berdiri tepat di belakang garis start.

(2) Dengan aba-aba "siap", peserta siap untuk berlari dengan start berdiri. 
(3) Dengan aba-aba "ya", peserta berlari secepat-cepatnya dengan menempuh jarak 30 meter sampai garis akhir.

(4) Kecepatan lari dihitung dari saat aba-aba "ya".

(5) Pencatatan waktu dilakukan sampai dengan persepuluh detik (0,1detik), bila memungkinkan dicatat sampai dengan perseratus detik (0,01 detik).

(6) Tes dilakukan dua kali. Pelari melakukan tes berikutnya setelah berselang minimal satu pelari. Kecepatan lari yang terbaik yang dihitung.

(7) Tes masih bisa diulang, apabila peserta mencuri start, tidak melewati garis finish, terganggu leh pelari lainnya dan terpeleset.

(8) Lebih jelasnya berikut adalah ilustrasi gambar tes lari sprint 30 meter.

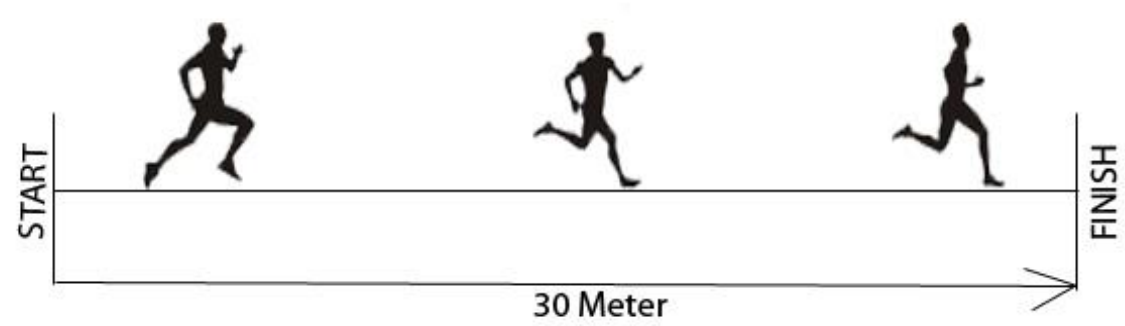

Gambar 1. Tes lari sprint 30 meter (Sriundy, 2014).

\section{Teknik Analisis Data}

Sesuai dengan hipotesis dan jenis penelitian yang digunakan dalam penelitian ini, maka analisis statistik yang digunakan adalah uji-t paired sample test dan Analisis of Varians (Anova) dengan taraf signifikansi $5 \%$ menggunakan program Statistical Product and Service Solution (SPSS) 21.0. untuk mengetahui pengaruh latihan acceleration sprints dan in-out sprint terhadap kecepatan.

\section{HASIL}

Pada deskripsi hasil penelitian ini membahas tentang rerata dan standar deviasi yang diperoleh dari hasil tes yang dilakukan pada masing-masing kelompok dihitung berdasarkan kelompok dan jenis latihan yang diterapkan.

1. Data hasil latihan acceleration sprints 
Wawan Setiawan, I Made Rajat Sanjaya \& Puji Setyaningsih | Pengaruh Latihan Acceleration Sprints dan Inout Sprint Terhadap Kecepatan

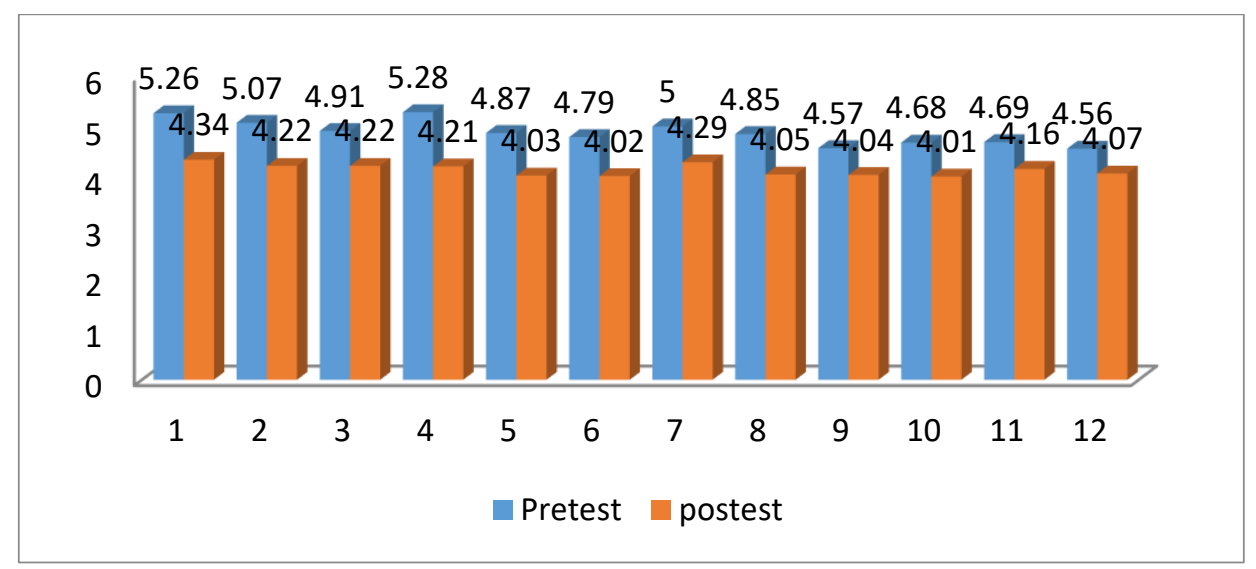

Berdasarkan hasil pengukuran dalam gambar diagram di atas pada kelompok I dapat dilihat bahwa terdapat sebuah peningkatan nilai rerata antara pretest dan posttest pada variabel dependent. Hal ini terbukti dari nilai rerata posttest dan nilai rerata pretest. Dimana dapat di lihat bahwa nilai rerata untukkecepatan hasil pengukuran posttest (49.66 $\mathrm{dtk}$ ), ini terlihat lebih tinggi dibanding dengan hasil pengukuran pretest (58.26 dtk) dan kelincahan dari hasil pengukuran posttest (140.24 dtk), ini terlihat lebih tinggi dibanding dengan hasil pengukuran pretest sebesar (144.51 dtk). Dalam pemberian treatment pada kelompok I dapat meningkatkan kecepatan.

2. Data hasil latihanin-out sprint

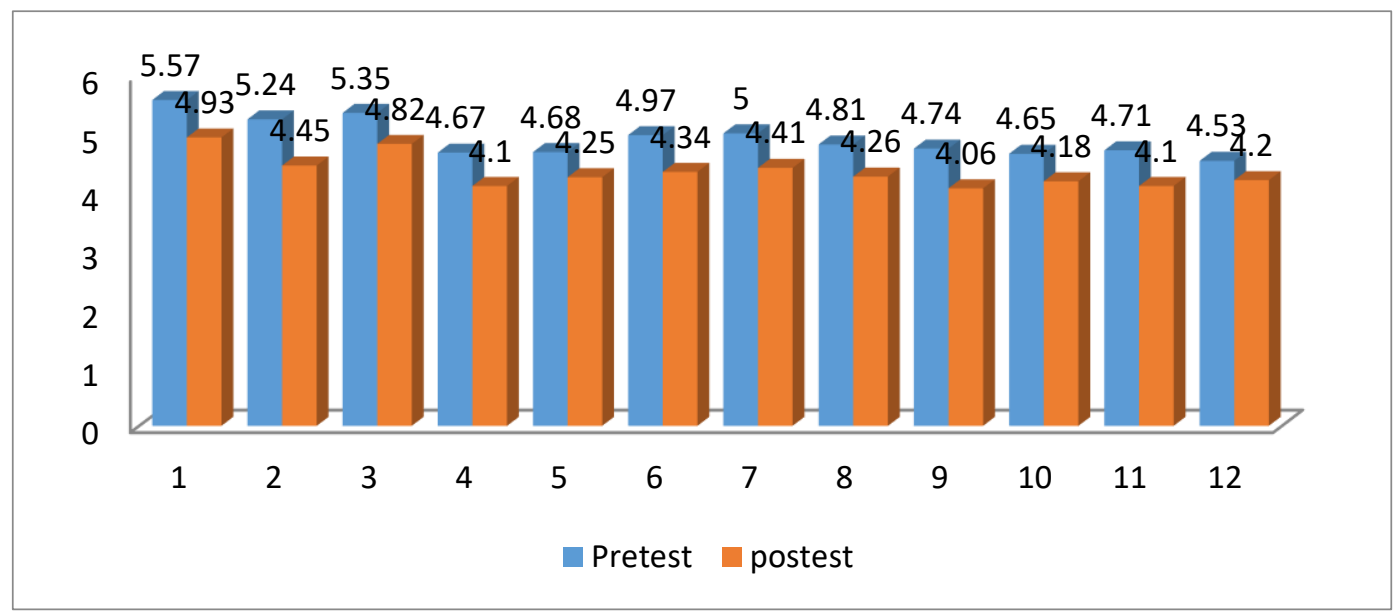

Berdasarkan hasil pengukuran dalam gambar diagram di atas pada kelompok II dapat dilihat bahwa terdapat sebuah peningkatan nilai rerata antara pretest dan posttest pada variabel dependent. Dimana dapat di lihat bahwa nilai rerata untuk kecepatanhasil pengukuran posttest (52.10 dtk), ini terlihat lebih tinggi dibanding dengan hasil pengukuran pretest (58,92 dtk) dankelincahan dari hasil pengukuran posttest (137.36 
dtk), ini terlihat lebih tinggi dibanding dengan hasil pengukuran pretest sebesar (143.56 dtk). Dalam pemberian treatment pada kelompok II dapat meningkatkan kecepatan dan kelincahan.

Uji analisis yang dipergunakan dalam penelitian ini adalah uji beda rerata (uji beda mean) dengan menggunakan analisis uji-t paired t-test. Nilai yang digunakan dalam penghitungan uji-t paired t-test adalah nilai pretest dan posttest dari masing-masing kelompok (kelompok I, kelompok II, dan kelompok III), dengan penyajian datanya hasil perhitungan uji-t paired t-test terlihat pada tabel 2 berikut ini.

Tabel 2. Hasil Uji Beda Rerata Sampel Berpasangan Kecepatan

\begin{tabular}{lllll}
\hline Kecepatan & & Mean & \multicolumn{1}{c}{$\begin{array}{l}\text { Sig. } \\
\text { tailed) }\end{array}$} & \\
\cline { 1 - 3 } Kelompok I & pre-test & 4.8775 & 0.000 & Keterangan \\
\cline { 2 - 3 } & post-test & 4.1383 & & \\
\hline Kelompok II & pre-test & 4.9100 & 0.000 & Signifikan \\
\cline { 2 - 3 } & post-test & 4.2158 & & \\
\hline Kelompok III & pre-test & 5.0142 & 0.090 & Tidak Signifikan \\
\cline { 2 - 3 } & post-test & 4.9383 & & \\
\hline
\end{tabular}

Berdasarkan tabel di atas hasil perhitungan uji beda rerata sampel berpasangan menggunakan uji-t paired t-test sebagai berikut:

1) Kelompok I (Acceleration Sprints)

Hasil perhitungan uji-t paired t-test pada pemberian latihan acceleration sprintsdengan melihat nilai Sig. (2-tailed) 0,000, Maka dapat disimpulkan bahwa Ho ditolak dan $\mathrm{Ha}$ diterima karena nilai Sig. $0.000<$ nilai $\alpha=0.05$. Dengan kata lain terdapat pengaruh yang signifikan dari pemberian latihan acceleration sprints terhadap kecepatan pada mahasiswa putra semester IV Penjaskesrek, FOK, Undiksha.

2) Kelompok II (In-out Sprint)

Hasil perhitungan uji-t paired t-test pada pemberian latihan in-out sprint dengan melihat nilai Sig. (2-tailed) 0.000, Maka dapat disimpulkan bahwa $\mathrm{Ho}$ ditolak dan $\mathrm{Ha}$ diterima karena nilai Sig. $0.000<$ nilai $\alpha=0.05$. Dengan kata lain terdapat pengaruh yang signifikan dari pemberian latihan in-out sprint terhadap kecepatan pada mahasiswa putra semester IV Penjaskesrek, FOK, Undiksha. 
Wawan Setiawan, I Made Rajat Sanjaya \& Puji Setyaningsih | Pengaruh Latihan Acceleration Sprints dan Inout Sprint Terhadap Kecepatan

Tabel 3. Uji Beda Rerata antar Kelompok (Anova)

\begin{tabular}{llllll}
\hline Sumber Variasi & Df & $\boldsymbol{F}$ & Sig. & Sig. & Keterangan \\
& \multicolumn{5}{c}{ hitungKecepatan } \\
\cline { 1 - 2 } Antar Kelompok & 2 & 220,286 & 0,000 & 0,000 & Signifikan \\
\cline { 1 - 2 } Dalam Kelompok & 33 & & & \\
\cline { 1 - 2 } Total & 35 & & & & \\
\hline
\end{tabular}

Berdasarkan tabledi atas menunjukan hasil perhitungan uji beda antar kelompok menggunakan One Way Anova dapat disimpulkan bahwa terdapat hasil rerata yang beda antar kelompok, karena hasil perhitungan menunjukkan nilai Sig. 0,000 < nilai $a=0.05$ dan nilai Sig. $0.000<$ nilai $a=0.05$, maka dapat dikatakan bahwa $\mathrm{Ho}$ ditolak dan $\mathrm{Ha}$ diterima. Dengan kata lain bahwa terdapat perbedaan yang signifikan antara hasil latihan kelompok acceleration sprints, kelompok in-out sprint, dan kelompok kontrol terhadap kecepatan.

Tabel 4. Hasil Perhitungan Post Hoc Test Kecepatan

Multiple Comparisons

Dependent Variable: Kecepatan

$\begin{array}{lllll}\text { (I) Kelompok } & \text { (J) Kelompok Latihan Mean Std. }\end{array}$ Latihan

Difference Error

$(\mathrm{I}-\mathrm{J})$

\begin{tabular}{llllll}
\hline LSD & $\begin{array}{l}\text { Acceleration } \\
\text { Sprints }\end{array}$ & In-out Sprint & 0,07500 & 0,04786 & 0,127 \\
\cline { 2 - 5 } & Kontrol & 0,90500 & 0,04786 & 0,000 \\
\hline \multirow{2}{*}{ In-out Sprint } & Acceleration Sprints & $-0,07500$ & 0,04786 & 0,127 \\
\cline { 2 - 5 } & Kontrol & 0,83000 & 0,04786 & 0,000 \\
\hline \multirow{2}{*}{ Kontrol } & Acceleration Sprints & $-0,90500$ & 0,04786 & 0,000 \\
\cline { 2 - 5 } & In-out Sprint & $-0,83000$ & 0,04786 & 0,000 \\
\end{tabular}

Berdasarkan hasil perhitungan tabel di atas dapat di interpretasikan sebagai berikut:

1) Kelompok acceleration sprints dan in-out sprint mempunyai nilai sig. $0,127>$ nilai $\mathrm{a}=0,05$ berarti $\mathrm{H}_{0}$ diterima dan $\mathrm{H}_{1}$ ditolak berarti tidak ada perbedaan yang signifikan antara kedua kelompok yaitu sebesar 0,07500 
2) Kelompok acceleration sprints dan kontrol mempunyai nilai sig. 0,000< nilai $\mathrm{a}=0,05$ berarti $\mathrm{H}_{0}$ ditolak dan $\mathrm{H}_{1}$ diterima berarti ada perbedaan yang signifikan yaitu sebesar 0,90500

3) Kelompok in-out sprint dan kontrol mempunyai nilai sig. 0,000 < nilai $a=$ 0,05 berarti $\mathrm{H}_{0}$ ditolak dan $\mathrm{H}_{1}$ diterima berarti ada perbedaan yang signifikan yaitu sebesar 0,83000

Berdasarkan uraian di atas menunjukan bahwa hasil latihan acceleration sprints, in-out sprint dan kontrol ternyata bervariasi. Nilai rerata yang dihasilkan menunjukan bahwa latihan acceleration sprints mempunyai pengaruh yang berbeda secara signifikan dari kelompok kontrol tetapi tidak berbeda secara signifikan dari latihan in-out sprint dan latihan in-out sprint mempunyai pengaruh berbeda secara signifikan dari kelompok kontrol terhadap kecepatan pada mahasiswa putra semester IV Penjaskesrek, FOK, Undiksha. Dengan hasil deskriptif diatas menyatakan bahwa pemberian latihan pada kelompok I dan II dapat meningkatkan kecepatan pada mahasiswa putra semester IV Penjaskesrek, FOK, Undiksha.

\section{PEMBAHASAN}

Dari perhitungan 'mean' didapatkan bahwa hasil rerata kecepatan setelah menerima pemberian latihan acceleration sprints meningkat. Hal ini sejalan dengan penelitian yang dilakukan oleh Manikandan (2014) dan Ambara (2011), Setelah dilakukan uji signifikansi ternyata hasilnya adalah signifikan, hal ini dapat dikatakan bahwa pemberian latihan acceleration sprints benar-benar berpengaruh positif terhadap peningkatan kecepatan. Latihan acceleration sprints ini dilakukan dengan cara membangun kecepatan, dengan berlari cepat dan bertahap meningkat mulai dari jogging, striding dan sprint, dilakukan secara berulang-ulang dapat menggunakan jarak tempuh 50 sampai 100 meter (Deuster et al., 2013). Pola gerakan latihan tersebut memberikan bukti nyata bahwa acceleration sprints merupakan salah satu bentuk latihan dengan fokus peningkatan kecepatan pada mahasiswa putra semester IV Penjaskesrek, FOK, Undiksha.

Dari perhitungan 'mean' didapatkan bahwa hasil rerata kecepatan setelah menerima pemberian latihan in-out sprint meningkat. Hal ini sejalan dengan penelitian yang dilakukan oleh Gunawan (2013) bahwa latihan in-out sprint dapat meningkatkan 
Wawan Setiawan, I Made Rajat Sanjaya \& Puji Setyaningsih | Pengaruh Latihan Acceleration Sprints dan Inout Sprint Terhadap Kecepatan

kecepatan. Setelah dilakukan uji signifikansi ternyata hasilnya adalah signifikan, hal ini dapat dikatakan bahwa pemberian latihan in-out sprint benar-benar berpengaruh positif terhadap peningkatan kecepatan. Latihan in-out sprint ini dilakukan dengan cara memposisikan diri pada garis start dan memulai secara bertahap membangun kecepatan sehingga mencapai penanda pertama (20 meter), pada zona berikutnya (20-40 meter) menambah kecepatan (kecepatan tinggi) pandangan tetap focus kedepan, langkah maksimal dan cepat untuk mendapatkan kecepatan maksimal, setelah melewati akhir zona, mulai memperlambat kecepatan pada zona terakhir (40-60 meter). Pola gerakan latihan tersebut memberikan bukti nyata bahwa in-out sprint merupakan salah satu bentuk latihan dengan fokus peningkatan kecepatan pada mahasiswa putra semester IV Penjaskesrek, FOK, Undiksha.

Pengaruh latihan acceleration sprints, in-out sprint dan kontrol memiliki perbedaan pengaruh yang signifikan terhadap peningkatan kecepatan. Pengaruh latihan acceleration sprints memberikan hasil yang lebih baik dari pada pemberian latihan in-out sprint terhadap kecepatan pada mahasiswa putra semester IV Penjaskesrek, FOK, Undiksha. Hal ini dapat dilihat dari proses latihan acceleration sprints dilakukan dengan berlari cepat dan bertahap meningkat sedangkan pada gerakan latihan in-out sprint berlari cepat namun ada gerakan untuk memperlambat kecepatan berlari.

Pada latihan acceleration sprints sangat efektif untuk melatih frekuensi langkah, langkah panjang, dan minimalisasi resiko cedera. Sehingga langkah panjang pada lari cepat akan berpengaruh terhadap efektifitas kecepatan lari (Gunawan, 2013). Sedangkan pada latihan in-out sprint kecepatan saat berlari tidak bertahap dan ada gerakan untuk memperlambat kecepatanberlari.

Acceleration sprints dan in-out sprint merupakan jenis latihan yang bertujuan untuk meningkatkan kecepatan. Kecepatan sebagai landasan yang mendasari dalam pembentukkan komponen biomotor, diperlukan komponen fisik yang penting agar tercapainya prestasi optimal. Dengan hasil penelitian ini dapat disimpulkan bahwa latihan acceleration sprints lebih baik dalam meningkatkan kecepatan pada mahasiswa putra semester IV Penjaskesrek, FOK, Undiksha. 


\section{SIMPULAN}

Berdasarkan hasil penelitian dan pembahasan yang telah diuraikan, maka dapat dikemukakan simpulan penelitian yaitu terdapat pengaruh yang signifikan latihan acceleration sprints terhadap kecepatan, terdapat pengaruh yang signifikan latihan in-out sprint terhadap kecepatan dan tidak terdapat perbedaan pengaruh yang signifikan antara latihan acceleration sprints dan in-out sprint terhadap kecepatan pada Mahasiswa PJOK putra semester IV Penjaskesrek.

Berdasarkan hasil penelitian ini, maka peneliti menyampaikan saran-saran, kepada para atlet, pelatih dan para ilmuwan pelatihan, dimana para atlet dan pelatih sebaiknya menerapkan program latihan acceleration sprints karena telah terbukti memberikan hasil yang lebih baik daripada program latihan in-out sprint terhadap peningkatan kecepatan dan menerapkan program latihan in-out sprint jika ingin meningkatkan kelincahan karena latihan in-out sprint telah terbukti memberikan hasil yang lebih baik dari pada program latihan acceleration sprints. Penelitian mendatang untuk program latihan acceleration sprints dan in-out sprint perlu diterapkan pada subjek yang berbeda (seperti: wanita, anak-anak, orang tua, atlet menengah dan terlatih). Pemberian program latihan harus memperhatikan prinsip-prinsip sesuai dengan karakteristik dan tingkatan, terutama dalam penentuan set dan repetisi agar tercapai hasil yang maksimal tanpa mengalami overtraining.

\section{Daftar Pustaka}

Ambara, I. K. A. W. (2011). Perbandingan Pengaruh Metode Latihan Acceleration Sprints, Hollow Sprints, dan Repetition Sprints Terhadap Peningkatan Prestasi Lari 100 Meter Ditinjau Dari Kekuatan Otot Tungkai (Studi Eksperimen Pada Mahasiswa Putra Jurusan IKOR, FOK-Undiksha Singaraja). Tesis. Surakarta: Program Pascasarjana. Sebelas Maret.

Deuster, P. A., Pelletier, P. A., \& Singh, A. (2013). The US Navy Seal Guide to Fitness and Nutrition. Skyhorse Publising Company.

Gamble, P. (2012). Training for Sports Speed and Agility. In Prepress Projects Ltd. Perth, UK: Routledge.

Gatz, G. (2009). Complete Conditioning For Soccer. Human Kinetics. 
Wawan Setiawan, I Made Rajat Sanjaya \& Puji Setyaningsih | Pengaruh Latihan Acceleration Sprints dan Inout Sprint Terhadap Kecepatan

Gunawan, I. W. R. (2013). Penerapan Latihan Acceleration Sprints dan In-Out Sprint Terhadap Prestasi Lari 100 Meter Ditinjau Dari Fleksibilitas Togok. Tesis. Surakarta: Program Pascasarjana. Sebelas Maret.

Lakshmikrishnan, R., \& Sivakumar, K. (2013). Effect Of Weight Training And Plyometric Training On Strength Endurance And Leg Strength. International Journal of Health, Physical Education and Computer Science in Sports, 11(1), 152-153.

Maksum, A. (2012). Metodologi Penelitian dalam Olahraga. Surabaya: Unesa University Press.

Manikandan, S. (2014). Efficacy Of Acceleration Sprint Training On Speed Performance Of Inter Collegiate Athletes. Asian Journal Of Physical Education and Computer Science In Sports, 11(1), 4-5.

Ratamess, N. (2012). ACSM's Foundations of Strength Training and Conditioning. USA: American College of Sports Medicine.

Sriundy, I. (2014). Pengantar Evaluasi Pengajaran. Surabaya: Unesa University Press.

Sucharitha, B. ., Reddy, A. ., \& Madhavi, K. (2014). Effectiveness Of Plyometric Training On Anaerobic Power And Agility In Female Badminton Players. International Journal Of Pharmaceutical Research And Bio-Science, 3(4), 754-761.

Sudhesh, P. (2013). Influence Of Eccentric Training On Non Dominant Hamstring Strength In Sprinters. International Journal of Pharma and Bio Sciences, 4(4), 1166-1170.

Sukadiyanto, \& Muluk, D. (2011). Pengantar Teori dan Metodologi Melatih Fisik. Bandung: CV. LUBUK AGUNG. 